\title{
Vermistabilization of sewage sludge (biosolids) by earthworms: converting a potential biohazard destined for landfill disposal into a pathogen-free, nutritive and safe biofertilizer for farms
}

\author{
Rajiv K. Sinha, Sunil Herat, Gokul Bharambe, Ashish Brahambhatt \\ Griffith School of Engineering (Environment), Griffith University, Nathan Campus, Brisbane, Queensland, Australia
}

\begin{abstract}
Earthworms feed readily upon sludge components, rapidly converting them into vermicompost, reduce the pathogens to safe levels and ingest the heavy metals. Volume is significantly reduced from $1 \mathrm{~m}^{3}$ of wet sludge ( $80 \%$ moisture) to $0.5 \mathrm{~m}^{3}$ of vermicompost (30\% moisture). Earthworms have real potential both to increase the rate of aerobic decomposition and composting of organic matter and also to stabilize the organic residues in the sludge - removing the harmful pathogens (by devouring them and also by discharge of antibacterial coelomic fluid) and heavy metals (by bio-accumulation). They also mineralize the essential nutrients nitrogen, phosphorus and potassium from the sludge. It may not be possible to remove toxic substances completely, but at least change the 'chemical make-up' of the sludge to make it harmless to the soil and enable its use as a nutritive organic fertilizer. This method has been found to comply with grade A standards for sludge stabilization.
\end{abstract}

Keywords: biosolids, earthworms, vermicomposting, organic fertilizer, sewage sludge, sludge hygienisation

\section{Introduction}

Sludge is an inevitable, hazardous and odorous by-product from conventional water and waste-water treatment plants which eventually requires safe disposal either in landfills or by incineration incurring heavy cost. When sludge is dewatered and dried, the residue is termed 'biosolids'. Management of biosolids remains problematic due to the high cost of installing sewage sludge stabilization reactors and dehydration systems.

Sewage sludge is a potential health hazard as it contains high numbers of cysts of protozoa, parasitic ova, faecal pathogens like Salmonella spp., Shigella spp. and Escherichia coli and also heavy metals such as zinc, cadmium, mercury and copper. In addition, sludge contains organic molecules and essential plant nutrients like nitrogen, phosphorus, potassium and various trace elements. When stabilized through a composting process, it can become a good source of organic fertilizer and soil additive, free of chemicals and pathogens.

Earthworms feed readily upon the sludge components, rapidly converting them into vermicompost, reduce the pathogens to safe levels and ingest the heavy metals. Volume is significantly reduced from $1 \mathrm{~m}^{3}$ of wet sludge (80\% moisture) to $0.5 \mathrm{~m}$ of vermicompost (30\% moisture; Eastman 1999).

\section{Earthworms - the great waste and environmental managers of the planet}

A revolution is unfolding in vermiculture studies (rearing of earthworms - Sir Charles Darwin's 'unheralded soldiers' of mankind) for total and sustainable waste management virtually creating 'wealth' from the 'waste'. The Greek philosopher Aristotle called them 'intestine of earth', meaning they digest a wide variety of organic materials from earth (Darwin \& Seward 1903, (Fraser-Quick 2002). Earthworms have over 600 million years of experience as waste and environmental managers of bio-waste, including human waste. 


\section{Environmental adaptations of earthworms}

Worms are adapted to survive in harsh environments and in moderately acidic-to-alkaline conditions with $\mathrm{pH}$ values ranging from 4.5 to 9 . They can tolerate a temperature range of $5-29^{\circ} \mathrm{C}$. A temperature of $20-25^{\circ} \mathrm{C}$ and moisture level of $60-75 \%$ is optimum for good worm function (Hand 1988). They are tolerant to moderate salt salinity and can also tolerate toxic chemicals including heavy metals. Some species (e.g. Eisenea foetida) have been found to bio-accumulate up to $7600 \mathrm{mg} \mathrm{Pb} \mathrm{g}^{-1}$ dry weight of their tissue (Ireland 1983) and withstand extremely toxic chemicals like TCDD $(2,3,7,8-$ tetrachlorodibenzo-p-dioxin; Satchell 1983).

\section{Rapid rate of multiplication and increase in population}

Earthworms are bisexual animals and reproduce rapidly. Given optimal conditions of moisture, temperature and feed, worms can multiply by $2^{8}$ (i.e. 256 worms) every 6 months from a single individual doubling their population at least every 60-70 days (Hand 1988).

\section{Species suitable for vermistabilization of sewage sludge} Long-term research into vermiculture has indicated that the Tiger Worm (E. foetida), Red Tiger Worm (Eisenia andrei), the Indian Blue Worm (Perionyx excavatus), the African Night Crawler (Eudrilus euginae), and the Red Worm (Lumbricus rubellus) are best suited for vermicomposting of sewage sludge under all climatic conditions.

\section{Earlier studies on vermistabilization of sewage sludge}

Vermicomposting has been successfully used for treating and stabilizing municipal as well as industrial (paper mill, dairy and textile industry) sludge as well as effluents and sludge from intensively housed livestock (Collier 1978, Hartenstein \& Bisesi 1989, Ceccanti \& Masciandaro 1999, Elvira et al. 1998, Ndegwa \& Thompson 2001, Fraser-Quick 2002, ContrerasRamos et al. 2005). Aerobic and anaerobic sludge are mixed and aerated for more than 15 days. To $5000 \mathrm{~m}^{3}$ of sludge are added $5 \mathrm{~kg}$ of earthworms and, in about 8 months, it is converted into vermicompost.

Contreras-Ramos et al. (2005) studied the vermicomposting of dried municipal sewage sludge and those from textile industries mixed with cow manure and oat straw. Cow manure was added to provide additional nutrients and the oat straw to provide bulk. Fifty earthworms (E. foetida) were added to each sample which were vermicomposted at three different moisture contents $-60 \%, 70 \%$ and $80 \%$ for 60 days. Volatile solids in the vermicompost decreased by 5 times, heavy metal concentrations and pathogen levels (with no coliforms) were below the limits set by USEPA (1995). Carbon content decreased significantly and the number of earthworms increased by 1.2 -fold.

\section{Large-scale vermicomposting of sewage sludge in Australia}

Vermiprocessing of sludge from sewage and water treatment plants is being increasingly practiced in Australia; as a result, it is saving over 13,000 $\mathrm{m}^{3}$ of landfill space every year in Australia (Komarowski 2001). Redland Shire in Queensland started vermicomposting sludge in 1997 with the help of the Vermitech company. The facility received 400-500 tons of sludge every week with $17 \%$ average solid contents and over 200 tons of vermicast was produced every week (Vermitech 1998, Lotzof 2000).

Hobart City Council in Tasmania vermicompost and stabilize about $66 \mathrm{~m}^{3}$ of sewage sludge every week, along with green mulch. Zeolite mixed with the sludge helps balance the $\mathrm{pH}$ and also in absorbing ammonia and odour. About $44 \mathrm{~m}^{3}$ becomes 'vermi-compost' which is sold to farmers (Datar et al. 1997).

\section{Mechanism of worm action in vermistabilization}

Vermistabilization is a complex mechanical and biochemical transformation of sludge achieved through the action of earthworms. The worms act as an aerator, grinder, crusher, chemical degrader and a biological stimulator (Sinha et al. 2002). Worms decompose the organic fraction in the sewage sludge, mineralize the nutrients, ingest the heavy metals and devour the pathogens (bacteria, fungi, nematodes and protozoa). Essentially, they work as a 'sludge digester':

1. The sludge is softened by the grume excreted in the mouth of the earthworms and from there it goes to the oesophagus.

2. In the oesophagus, the softened sludge components are neutralized by calcium (excreted by the inner walls of oesophagus) and passed on to the gizzard and the intestine for further action.

3. In the muscular gizzard, it is finely ground (with the aid of stones) into small particles to a size of $2-4 \mu \mathrm{m}$ and passed on to the intestine for enzymatic digestion. The gizzard and the intestine work as a 'bioreactor'.

4. In the intestine, the ground and pulped sludge components are decomposed by proteases, lipases, amylases, cellulases and chitinases secreted here and then absorbed.

5. The final process in vermiprocessing and degradation of sludge is humification in which the large organic particles are converted into complex amorphous colloids containing phenolic materials. Finally, this stabilized sludge is discharged as excreta (vermicast).

\section{Earthworms reinforce microbial populations in sewage sludge that act synergistically in sludge stabilization}

Earthworms stimulate and accelerate the population of decomposer microbes in waste biomass through improving aeration (Dash 1978, Binet et al. 1998). They also host millions of decomposer microbes in their gut and excrete them along with nutrients nitrogen and phosphorus in their excreta (Singleton et al. 2003). The nitrogen and phosphorus are further used by the microbes for multiplication and enhanced action. Edward \& Fletcher (1988) showed that the number of bacteria and Actinomycetes contained in the ingested material increased up to 1000 -fold while passing through the gut. A population of worms numbering about 
15,000 will foster a microbial population of billions (Morgan \& Burrows 1982). Singleton et al. (2003) studied the bacterial flora associated with the intestine and vermicasts of the earthworms and found species like Pseudomonas, Mucor, Paenibacillus, Azoarcus, Burkholderia, Spiroplasm, Acaligenes, and Acidobacterium which has the potential to degrade a range of organic molecules. Acaligenes spp. can even degrade PCBs and Mucor spp. dieldrin.

Under favourable conditions, earthworms and microbes act symbiotically to accelerate and enhance the decomposition of the organic matter in the sludge (Morgan \& Burrows 1982, Xing et al. 2005).

\section{Factors affecting optimal worm activity and sludge stabilization}

The role of earthworms in the stabilization of sewage sludge is greatly linked to sludge age and nutrient content, aerobic conditions, moisture content, temperature, ash content and the loading rate (Dominguez et al. 2000, Masciandaro et al. 2000).

\section{Sludge age and nutrient content}

Nutritional value of the sludge especially nitrogen and phosphorus content is important. As the sludge ages, its nutritive value declines rapidly after about 12 weeks, but the ash content increases which is good for worms (Loehr et al. 1998).

\section{Adequate aeration}

Although worms constantly aerate the waste pile by burrowing actions, periodical turning of the sludge can improve aeration and biodegradation. Aeration also makes the sludge more palatable to worms.

\section{Adequate moisture}

About $75 \%$ moisture is recommended for sludge digestion. Neuhauser et al. (1988) recommended 80-90\%. If it is too wet, it may become anaerobic, adversely affecting worm activity.

\section{Moderate temperature}

The ideal temperature for sludge composting and stabilization by earthworms is $15-25^{\circ} \mathrm{C}$ (Neuhauser et al. 1988).

\section{Neutral pH (7.0)}

Although worms can survive in a $\mathrm{pH}$ range of 4.5-9 they function best at neutral $\mathrm{pH}$ 7.0. Worms can also adjust the $\mathrm{pH}$ of the medium by secreting calcium.

\section{Appropriate carbon/nitrogen $(\mathrm{C} / \mathrm{N})$ ratio of the feed material}

A $\mathrm{C} / \mathrm{N}$ ratio of 25 is considered good for vermicomposting and stabilization of sewage sludge and reduction of volatile solids. Sewage sludge may have low $\mathrm{C} / \mathrm{N}$ ratio due to higher nitrogen content. This can be improved by mixing in carbonrich 'bulking materials' such as straw and decaying leaves.

\section{Adequate supply of calcium}

Calcium appears to be an important mineral in worm biology (as calcarious tissues) and biodegradation activity. Although sewage sludge contains calcium, it is important to add some additional sources of calcium for good vermicomposting. Egg shells are a good source of natural calcium. Occasionally, limestone powder should be added.

\section{Advantages of vermistabilization of sewage sludge by earthworms}

The quality of vermicompost upon stabilization is significantly better, rich in key minerals and beneficial soil microbes as compared to the conventional composting which is thermophilic (temperature rising up to $55^{\circ} \mathrm{C}$ ) in which many beneficial microbes are killed and nutrient especially nitrogen is lost (due to gassing off of nitrogen). Worms also keep the system fully aerated and aerobic processes are about 10 times faster than anaerobic processes.

\section{Nearly odour-free process}

As worms create aerobic conditions in the waste materials by their burrowing actions, the action of anaerobic microbes which release foul-smelling hydrogen sulphide and mercaptans is inhibited.

\section{Worms destroy pathogens in the end-product making it pathogen-free}

The earthworms release coelomic fluids that have antibacterial properties and destroy all pathogens in the waste biomass (Pierre et al. 1982). They also devour protozoa, bacteria and fungi as food. They seem to realize instinctively that anaerobic bacteria and fungi are undesirable and so feed upon them preferentially, thus arresting their proliferation.

In the intestine of earthworms, some bacteria and fungi (Penicillium spp. and Aspergillus spp.) have also been found (Singelton et al. 2003). They produce antibiotics which kill the pathogenic organisms in the sewage sludge making it virtually sterile. The removal of pathogens, faecal coliforms $(E$. coli), Salmonella spp., enteric viruses and helminth ova from sewage and sludge appears to be much more rapid when they are processed by E. foetida. Of all, E. coli and Salmonella are greatly reduced (Bajsa et al. 2003).

Bajsa et al. (2004, 2005) studied pathogen removal in vermicomposting of sewage sludge spiked with E. coli, S. typhimurium and $E$. faecalis. The composting was done with different bulking materials such as lawn clippings, sawdust, sand and sludge alone for about 9 months. Safe product was achieved in 4-5 months of vermicomposting and the product quality remained the same in the remaining months of the test.

Lotzof (2000) also showed that pathogens like enteric viruses, parasitic eggs and $E$. coli were reduced to safe levels in sludge vermicasts. Cardoso \& Remirez (2002) reported a $90 \%$ removal of faecal coliforms and $100 \%$ removal of helminths from sewage sludge after vermicomposting. Our studies, Brahmbhatt (2006) also confirmed complete removal of coliforms by earthworms.

Nair et al. (2006) studied a combination of thermophilic treatment followed by vermicomposting and observed that the combination of leads to a faster reduction of pathogens 
Table 1: Removal of pathogens (E. coliand E. faecalis) in thermophilic composting vis-a-vis vermicomposting processes.

\begin{tabular}{|c|c|c|c|c|c|}
\hline \multirow{2}{*}{ Composting process } & \multirow{2}{*}{ Composting period } & \multicolumn{2}{|c|}{ E. coli (MPN/g) } & \multicolumn{2}{|c|}{ E. faecalis (MPN/g) } \\
\hline & & After 2 months & After 3 months & After 2 months & After 3 months \\
\hline Thermophilic & 21 days & $>110$ & 110 & $>110$ & 46 \\
\hline Vermicomposting & 21 days & 110 & 7.5 & 110 & 4.3 \\
\hline Thermo + Vermi & $6 d T \& 15 d V$ & 24 & 21 & 46 & 2.3 \\
\hline Thermo + Vermi & $9 \mathrm{dT} \& 12 \mathrm{dV}$ & 46 & 15 & 46 & 9.3 \\
\hline Thermo + Vermi & $12 d T \& 9 d V$ & 110 & 15 & 46 & 4.3 \\
\hline Thermo + Vermi & $15 \mathrm{dT} \& 6 \mathrm{dV}$ & $>110$ & 4.3 & 24 & 2.3 \\
\hline
\end{tabular}

Source, Nair et al. (2006).

$\mathrm{dT}$, days of thermophilic composting; $\mathrm{dV}$, days of vermicomposting.

E. coli and E. faecalis were tested using the Most Probable Number (MPN) per gram of compost (Standards Australia, 1995, a and b respectively).

than the same period of thermophilic composting (21 days). The study also indicated that vermicomposting leads to greater reduction of pathogens even after 3 months of storage, while samples subjected to thermophilic composting only retained higher levels of pathogens even after 3 months.

\section{Worms remove heavy metals and toxic chemicals from the end-product}

Earthworms (especially E. foetida) can bio-accumulate high concentrations of metals including heavy metals in their tissues without affecting their physiology and this particularly when the metals are mostly non-bioavailable. They can readily bio-accumulate cadmium, mercury, lead, copper, manganese, calcium, iron and zinc and extremely high amounts of $\mathrm{Zn}, \mathrm{Pb}$ and $\mathrm{Cd}$. Cadmium levels up to $100 \mathrm{mg} \mathrm{kg}^{-1}$ and lead up to $7600 \mathrm{mg} \mathrm{g}^{-1}$ dry weight have been found in tissues (Ireland 1983). Contreras-Ramos et al. (2005) confirmed that the stabilized sludge has metal levels below the limits set by the USEPA in 60 days. Our studies (Brahmbhatt 2006) confirmed significant removal of lead and cadmium from vermicomposted sewage sludge.

Some metals are protein-bound (so-called metallothioneins) in earthworms, these have a very high capacity to bind metals. The chloragogen cells in earthworms appear to accumulate heavy metals specifically which are immobilized in the small spheroidal chloragosomes and debris vesicles that the cells contain.

Several studies have found that earthworms can also either accumulate or degrade organochlorine pesticides and poly- cyclic aromatic hydrocarbon (PAH) residues in the medium in which they feed (Nelson et al. 1982; Ireland 1983, Sinha et al. 2008).

\section{Worms mineralize nutrients from the sludge and form more nutritive end-products rich in macro- and micronutrients}

Earthworms mineralize the nitrogen and phosphorus in sludge to make it bio-available to plants as nutrients. The end-products are more homogeneous, rich in $\mathrm{N}, \mathrm{K}$ and $\mathrm{P}$ ( $1.16 \%$ nitrogen, $1.34 \%$ potassium and $1.22 \%$ phosphorus), micronutrients, beneficial soil microbes (e.g. nitrogen-fixing bacteria and mycorrhizal fungi) and the levels of contaminants are significantly reduced (Lotzof 1999). McCarthy (2002) asserted that vermicomposted sewage sludge is safe for agricultural use. Chemical analyses of vermicasts showed two times more available magnesium, 15 times more available nitrogen and seven times more available potassium compared to the surrounding soil (Kaviraj \& Sharma 2003). Elvira et al. (1998) also reported an increase in the potassium content of sludge vermicompost. This is an excellent biofertilizer and soil conditioner (Jensen 1998). The resulting product appears to retain more nutrients for longer periods of time and also greatly increases the water holding capacity of farm soil (Hartenstein \& Hartenstein 1981, Appelhof 1997). Vermicompost made from sludge also contains enzymes like amylase, lipase, cellulase and chitinase, which continue to break down organic matter in the soil to release nutrients and make them bio-available to plant roots for longer periods.

Table 2: Initial and final nutritional quality of the vermicomposted sludges.

\begin{tabular}{|c|c|c|c|c|c|c|c|c|c|}
\hline & \multicolumn{2}{|c|}{$\mathrm{pH}$} & \multicolumn{2}{|c|}{ Nitrate $\left(\mathrm{g} \mathrm{kg}^{-1}\right)$} & \multicolumn{2}{|c|}{ Phosphate $\left(\mathrm{g} \mathrm{kg}^{-1}\right)$} & \multirow{2}{*}{$\frac{\text { Nitrogen }\left(\mathrm{mg} \mathrm{g}^{-1}\right)}{\text { Final }}$} & \multirow{2}{*}{$\begin{array}{c}\text { Carbon } \\
\text { Final }\end{array}$} & \multirow{2}{*}{$\frac{\mathrm{C} / \mathrm{N} \text { ratio }}{\text { Final }}$} \\
\hline & Initial & Final & Initial & Final & Initial & Final & & & \\
\hline $\mathrm{SL}$ & 9.5 & 4.5 & 0.5 & 3.75 & 6.2 & 5.13 & 35 & 33 & $9: 1$ \\
\hline $\mathrm{SL}+\mathrm{LC}$ & 9 & 5.0 & 2.25 & 3.00 & 2.45 & 5.80 & 38 & 34 & $9: 1$ \\
\hline$S L+S D$ & 8 & 4.5 & 5.5 & 3.00 & 6.52 & 2.90 & 12 & 26 & $22: 1$ \\
\hline$S L+S$ & 9.5 & 4.5 & 2.5 & 1.75 & 4.45 & 1.55 & 6.2 & 4.5 & $7: 1$ \\
\hline
\end{tabular}

Source: Bajsa et al. (2005).

SL, sludge; LC, lawn clippings; SD, sawdust; S, sand. 


\section{Worms decrease total organic carbon (TOC) and lower C/N ratio of sludge}

This has significance when the composted sludge is added to soil as fertilizer. Plants cannot absorb and assimilate mineral nitrogen unless the carbon to nitrogen $(\mathrm{C} / \mathrm{N})$ ratio is about 20:1 or lower. Mineralization of organic matter in sewage sludge by earthworms leads to a significant decrease in total organic carbon (TOC) content thus lowering the $\mathrm{C} / \mathrm{N}$ ratio. Elvira et al. (1998) found that vermicomposting of paperpulp-mill sludge for 40 days decreased carbon content by 1.7 fold.

\section{Worms reduce volatile solids from sludge}

Loehr et al. (1998) found that E. foetida increases the rate of volatile solid destruction when present in aerobic sludge and this reduces the probability of putrefaction occurring in the sludge due to anaerobic conditions. Hartenstein \& Hartenstein (1981) reported a 9\% reduction in volatile solids over 4 weeks of sludge vermicomposting by earthworms. Fredrickson et al. (1997) found a reduction in volatile solids of $30 \%$ in compost after 4 months of conventional composting, whereas the reduction was $37 \%$ after only 2 months of vermicomposting.

\section{Low greenhouse gas (methane) emission by vermicomposting}

Biodegradation of organic waste has long been known to generate methane. Vermicomposting by worms decreases the proportion of anaerobic to aerobic decomposition, resulting in a significant decrease in $\mathrm{CH}_{4}$ and volatile sulphur compounds which are readily emitted from conventional microbial composting (Mitchell et al. 1980, Sinha et al. 2008b). Molecule for molecule, methane is 20-25 times more powerful a greenhouse gas than the $\mathrm{CO}_{2}$.

\section{Production of worm biomass: a nutritive meal for the fishery. poultry and dairy industries}

Large-scale vermicomposting of sludge would result in the production of tons of worm biomass every year which is a 'pro-biotic' food for the poultry, dairy and fishery industries. 'Worm meal' is rich in the essential amino acids lysine and methionine.

\section{Experimental study of vermicomposting of sewage sludge at Griffith University, Australia.}

The objectives of the study were to assess the: (i) rapidity of sludge stabilization and maturity under different composting methods; and (ii) status of the heavy metals cadmium and lead, percentage of coliform bacteria and E. coli, and age of total organic carbon (TOC) in the untreated sludge (upon natural ageing) in vermicomposted and conventionally composted sludge.

\section{Material and methods}

Sewage sludge was obtained from a local sewage treatment plant in Brisbane and earthworms were cultured by The Worm Man in Australia. The worms mixed species of $E$. foetida, Perionyx excavatus and Eudrillus eugeniae. Cow dung was obtained from a cattle farm. Both sludge and the cow dung were partially air dried for 5 days to prevent any methane and hydrogen sulphide generation. Vermicompost was prepared in a glasshouse by composting food waste. Five sets of experimental bins (40-L HDPE containers) were prepared. They were studied for changes in colour and texture, pathogens and heavy metals over a 12 -week period. The bins were covered with moist newspaper and placed under shaded conditions to prevent moisture loss.

\section{Experimental design}

The five experimental designs were: treatment 1 , only sludge $(10 \mathrm{~kg})$ as control; treatment 2 , sludge $(10 \mathrm{~kg})+$ earthworms only $(n=250)$; treatment 3 , sludge $(10 \mathrm{~kg})+$ earthworms $(n=250)+$ cow dung $(5 \mathrm{~kg})$; treatment 4 , sludge $(10 \mathrm{~kg})+$ cow dung $(5 \mathrm{~kg})$; and treatment 5 , sludge $(10 \mathrm{~kg})+$ organic garden soil $(5 \mathrm{~kg})$.

These were designed to evaluate the following:

1. Treatment 1 was devised to determine the fate of sludge upon 'natural ageing' with time and by the natural microbial activity occurring in them.

2. Treatments 2 and 3 were designed to evaluate the fate of sludge after vermicomposting and worm action on sludge when the worms only feed on sludge and when they are provided with additional feed materials (cow dung).

3. Treatments 4 and 5 were organized to evaluate the fate of sludge after conventional microbial composting by addition of cow dung and organic rich garden soil, respectively, which are rich in decomposer microbes.

\section{Results}

The most significant results were:

1. There were no significant changes in the control sample for several weeks. There was rapid moisture loss and foul odour that continued up to week 12 . This was about $20 \%$ stabilized by week 12 .

2. Most significant and rapid changes were observed in Treatments 2 and 3 which contained earthworms. Foul odour disappeared by week 2 and the colour and texture of the sludge started changing to that of 'soil', which is an indication of the stabilization process that started in week 2 . By week 12, the black and brittle sludge became a homogeneous and porous mass of brown vermicast with light texture. The worms were active and agile, grew in size but not much in numbers. There was enough moisture and the sludge appeared to be stabilized by over $80 \%$ by week 12 .

3. Worm activity was more vigorous in Treatment 3 where cow dung was provided as additional feed for the worms. They were much healthier and more in numbers with several cocoons and baby worms indicating rapid rate of reproduction. By week 10, the black sludge became a homogeneous and porous mass of brown vermicast with lighter texture. There was greater retention of moisture. It was over $90 \%$ stabilized by week 12 . 


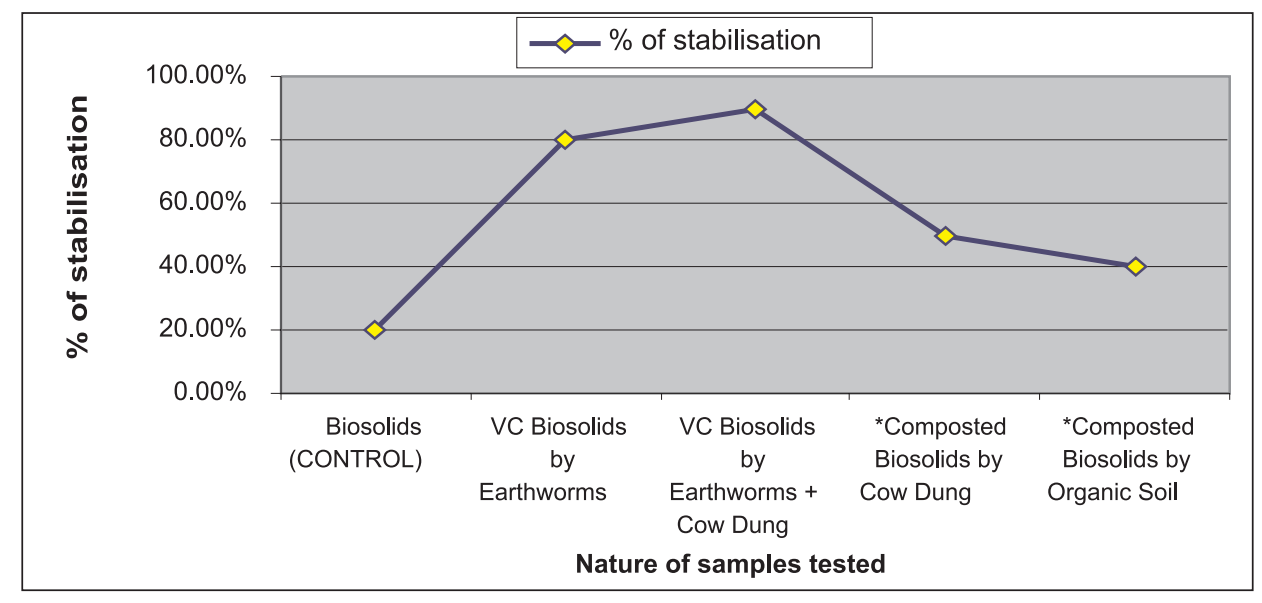

Fig. 1: Status of coliforms in the untreated (control), vermicomposted and conventionally composted sludge (biosolids) after 12-week period.

Table 3: Status of coliforms in the untreated (control), vermicomposted and conventionally composted sludge (biosolids) after 12-week period.

\begin{tabular}{llcc}
\hline & Sample tested & Stabilization (\%) & Colilert test under UV lamp \\
\hline 1. & Untreated sludge (control) & $20 \%$ & Positive \\
2. & VC sludge by earthworms only & $80 \%$ & Negative \\
3. & VC sludge by earthworms + cow cung & $90 \%$ & Negative \\
4. & ${ }^{*}$ Composted sludge with cow dung & $50 \%$ & Positive \\
5. & ${ }^{*}$ Composted sludge with organic soil & $40 \%$ & Positive \\
\hline
\end{tabular}

VC, Vermicomposted.

*Conventional composting by microbial degradation.

4. The changes occurring in Treatment 4 (sludge mixed with only cow dung) were slow, with odour continuing up to week 12. It was about $50 \%$ stabilized by week 12 .

5. The changes occurring in Treatment 5 (sludge mixed with organic soil) was also slow, with odour continuing up to week 12 . This too, was about $40 \%$ stabilized by week 12 .

\section{Status of coliforms in untreated, vermicomposted and conventionally composted sludge}

Tests for pathogens were made using Colilert reagent. White granules of Colilert powder were added to the samples and incubated for $24 \mathrm{~h}$ at $35^{\circ} \mathrm{C}$. The samples are tested under a UV lamp for colour changes after $24 \mathrm{~h}$ but before $28 \mathrm{~h}$. Yellow colour indicates the presence of total coliforms and the yellow colour with fluorescence indicates the presence of $E$. coli. If there is no colour change, it is free of pathogens.

A 1-g sample from Treatment 1 (12-week aged sludge) was taken in a polycarbonate sterile container and diluted with $100 \mathrm{ml}$ of sterile water in a laminar flow machine and tested under UV lamp. The colour was yellow with fluorescence indicating the presence of total coliforms in the untreated sludge even after ageing for 12 weeks.

Samples $(1 \mathrm{~g}$ ) from Treatments 2 and 3 (vermicomposted sludge) were taken and subjected to the same operation. There was no colour change indicating complete absence of coliforms and E. coli.

Samples (1 g) from Treatments 4 and 5 (conventionally composted sludge) were taken and subjected to same opera- tion. There was change in colour (yellow) indicating the presence of coliforms and E. coli.

\section{Discussion}

Results clearly show that the earthworms significantly reduced or almost eliminated the pathogens from the digested (vermicomposted) sludge. Sludge treated with earthworms (with or without feed materials) only showed negative results by the Colilert test under the UV lamp. This was achieved in just 12 weeks.

It also implies that, under the conventional composting systems by enhanced microbial degradation, pathogens will remain in the sludge for a longer period of time until it is completely dry with all food and moisture exhausted making it difficult for them to survive. That is why they are classed as biohazard and landfilled or incinerated.

Status of the heavy metals cadmium and lead in untreated, vermicomposted and conventionally composted sludge

Tests for the presence of the heavy metals cadmium and lead were done using atomic absorption spectroscopy. Samples were heated in an oven at $60^{\circ} \mathrm{C}$ for $48 \mathrm{~h}$, cooled in a desiccator and ground to $1 \mathrm{~mm}$ particle size. An air-dried sample $(1 \mathrm{~g})$ was digested with $5 \mathrm{ml}$ of concentrated nitric acid in a $75-\mathrm{ml}$ digestion tube for $3 \mathrm{~h}$ at $145^{\circ} \mathrm{C}$. The solution was allowed to cool for $48 \mathrm{~h}$ after which it was filtered through glass fibre in a funnel into a $25-\mathrm{ml}$ volumetric flask. The solution was then transferred into 50-ml Falcon tubes, centrifuged at $3000 \mathrm{rpm}$, 


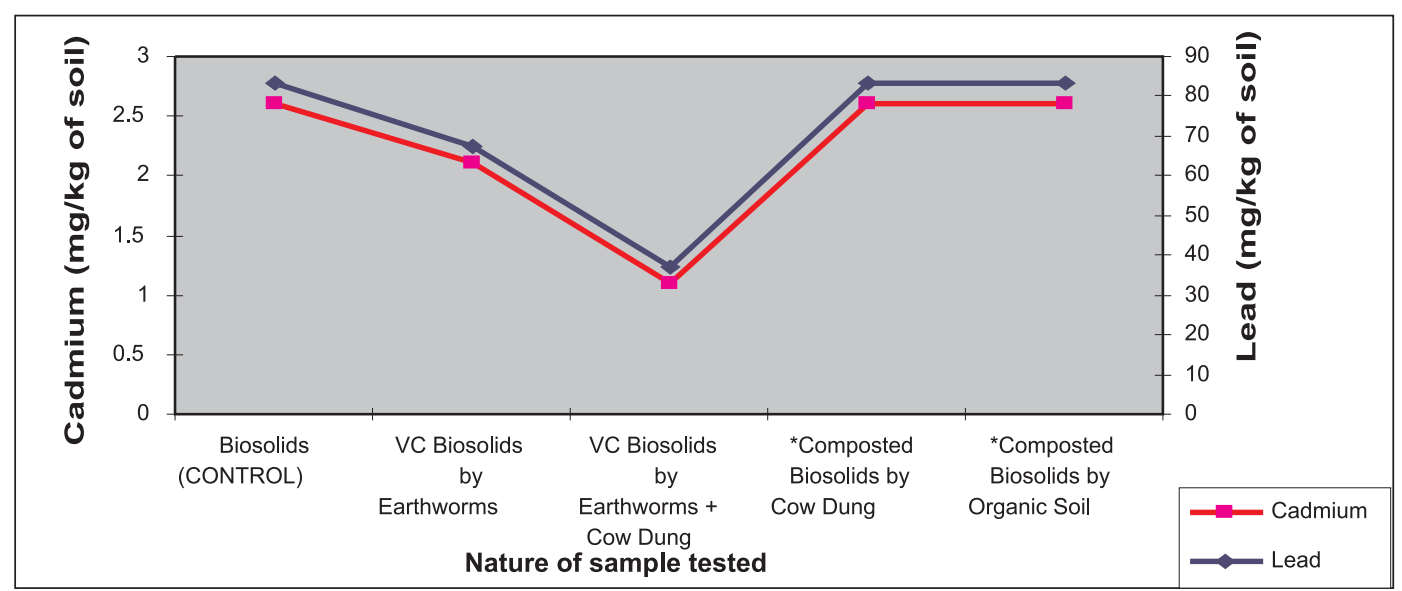

Fig. 2: Status of heavy metals cadmium and lead $(\mathrm{Pb})$ in the untreated (control), vermicomposted and conventionally composted sludge (biosolids) after 12-week period.

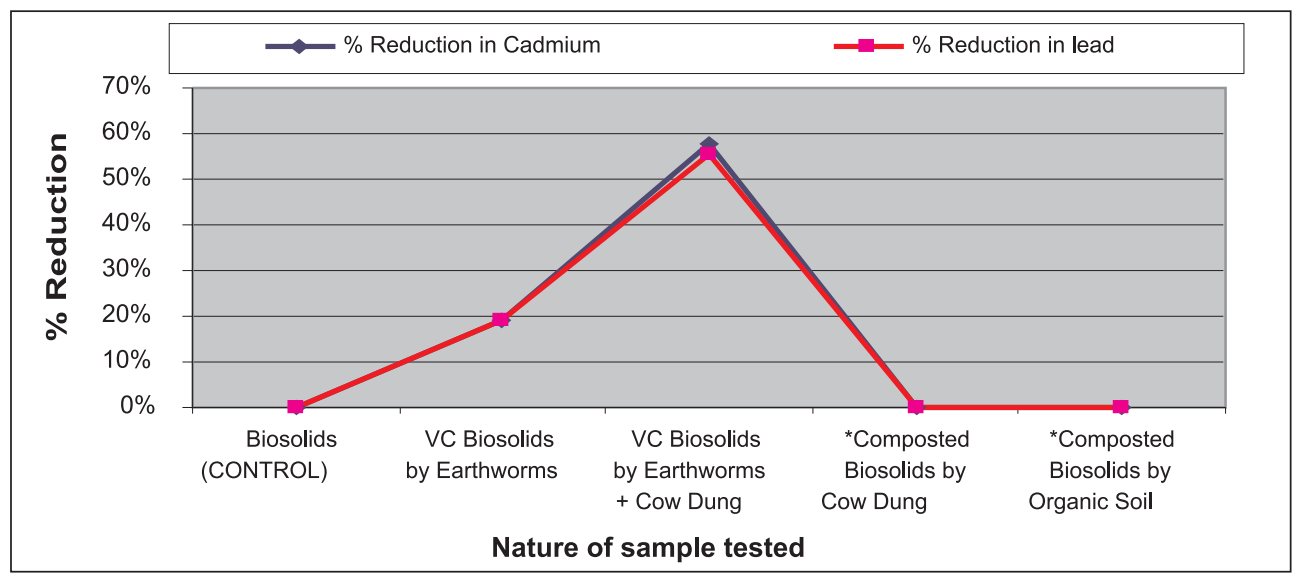

Fig. 3: Percentage reduction in cadmium and lead in the untreated (control), vermicomposted and conventionally composted sludge (biosolids) after 12-week period.

Table 4: Status of heavy metals cadmium and lead in the untreated (control), vermicomposted and conventionally composted sludge (biosolids: $\mathrm{mg} \mathrm{kg}^{-1}$ of soil) in 12-week period.

\begin{tabular}{llcc}
\hline & Sample tested & Cadmium (\% reduction) & Lead (\% reduction) \\
\hline 1. & Untreated sludge (control) & $2.6(-)$ & $83.2(-)$ \\
2. & Vermicomposted sludge by earthworms only & $2.1(19.23 \%)$ & $67.2(19.2 \%)$ \\
3. & Vermicomposted sludge by earthworms + cow dung & $1.1(57.70 \%)$ & $37.1(55.4 \%)$ \\
4. & $*$ Composted sludge + cow dung & $2.6(\mathrm{NC})$ & $83.2(\mathrm{NC})$ \\
5. & $*$ Composted sludge + organic soil & $2.6(\mathrm{NC})$ & $83.2(\mathrm{NC})$ \\
\hline
\end{tabular}

*Conventional composting by microbial degradation.

$N C$, no change in value.

and the supernatant tested for heavy metals in an atomic absorption spectrometer.

Results confirmed that the earthworms reduced cadmium and lead levels from the vermicomposted sludge (Table 4). There was no change in the values of heavy metals in the untreated sludge and sludge treated by adding only cow dung and organic soil (without worms) to enhance microbial composting. Although sludge can be slowly stabilized by microbial degradation over a period of time, the heavy metals will remain in the system for quite sometime after which it may leach into soil or bind with soil organic molecules.

Though there was no significant removal of heavy metals by earthworms in the 12 weeks of the experiment, their role in heavy metal removal cannot be undermined. Providing additional feed materials to enhance worm activity and also their number led to greater removal of heavy metals. This implies that over a period of time and with enhanced worm activity, heavy metals can be completely removed from the sludge. 
Table 5: Total organic carbon (TOC) in the untreated (control). vermicomposted and conventionally composted sludge (biosolids) in 12-week period.

\begin{tabular}{llc}
\hline & Sample tested & TOC (\%) \\
\hline 1. & Untreated sludge (control) & 64.15 \\
2. & Vermicomposted sludge by earthworms & 52.36 \\
3. $\quad$ Vermicomposted sludge by earthworms + & 41.36 \\
& $\quad$ cow dung & \\
4. $\quad{ }^{*}$ Composted sludge + cow dung & 58.16 \\
5. $\quad{ }^{*}$ Composted sludge + organic soil & 58.18 \\
\hline *Conventional composting by microbial degradation. &
\end{tabular}

Status of total organic carbon (TOC) in untreated, vermicomposted and conventionally composted sludge TOC was measured by heating $3 \mathrm{~g}$ of samples in crucibles (whose empty weight was recorded) in an oven at $50^{\circ} \mathrm{C}$ for 1 $\mathrm{h}$ so that all the carbon-containing organics were volatilized from the samples. They were then cooled in desiccators for $30 \mathrm{~min}$. The weight of the samples was recorded again to determine the amount of carbon content that volatilized. The difference in initial and final weights gave the value of total organic carbon in the samples.

Results clearly shows that vermicomposting of sludge can reduce the total organic carbon of sludge in much lesser time. This has significance in lowering the $\mathrm{C} / \mathrm{N}$ ratio so that nitrogen can be made bio-available to the plants.

\section{Problems encountered during vermicomposting of sewage sludge}

There is initial odour problem because the worms are overloaded with waste beyond their 'carrying capacity' at a given time and oxygen supply becomes insufficient leading to anaerobic conditions. As the worms grow and multiply over a period of time, they discharge more anti-pathogenic coelomic fluid, create more aerobic conditions in the waste biomass by burrowing actions, and devour the anaerobic microbes thus removing the odour problem.
However, a natural insoluble mineral zeolite (aluminium silicate) when mixed with sludge (3-5\%) reduces or eliminates the foul odour by absorbing the gases ammonia and hydrogen sulphide. Zeolite has additional advantages. Its cage-like skeletal structure traps heavy metals and prevents their leaching into the environment. It also helps to raise or lower $\mathrm{pH}$ of waste through cation exchange.

\section{Environmental and economic benefits of vermistabilization of sewage sludge}

Vermistabilization by vermicomposting involves about 100 1000 times higher 'value addition' in the system. Earthworms can compost and convert municipal and industrial sewage sludge into a valuable resource at a fraction of the cost of other methods and also divert them from ending up in landfills. Landfills are proving to be an economic and environmental burden (emitting greenhouse and toxic gases and the threat of groundwater contamination by leachate discharge) for nations. Classed as a biohazard, sewage sludge has to be necessarily disposed in secured landfill sites at still higher cost. The up-front cost of construction of an average secured landfill is estimated to be US\$ $15-25$ million before the first load of waste is dumped. This explains the dollar value of diverting every cubic metre of sludge from the landfills by vermicomposting. Some nations incinerate sewage sludge and the cost of incineration is both economic (in terms of high use of energy) and environmental (in terms of pollution).

Australia is saving over $13,000 \mathrm{~m}^{3}$ of landfill space every year by vermicomposting (Komarowski 2001). The Hobart City Council in Tasmania is saving AU $\$ 56,000$ per year just from avoiding landfill disposal and earning an equal amount (about AU $\$ 55,000)$ from the sale of vermicompost to the public (Datar et al. 1997). Redland Shire in Queensland saved over AU \$50,000 every year and earned an equal amount from the sale of vermicompost.

Economic and environmental benefits also accrue from the production and sale of live worms and their excreta (vermicompost). Together, they significantly improve soil fertility and food productivity is enhanced by over $30-40 \%$ as com-

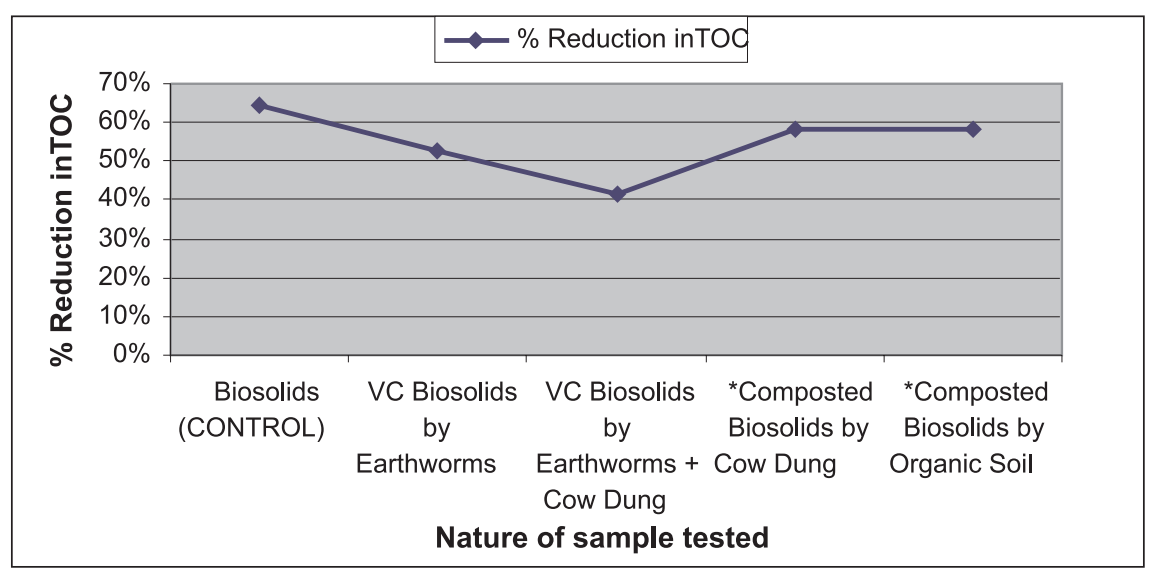

Fig. 4: Total organic carbon (TOC) in the untreated (control), vermicomposted and conventionally composted sludge (biosolids) after 12-week period. 
pared to chemical fertilizers as our study has shown (Sinha et al. 2009). The protein-rich 'worm meal' is supporting the fishery, poultry and dairy industries. The pharmaceutical industry is also finding a new use for earthworms in the manufacture of antibiotics from their anti-pathogenic coelomic fluid. The cost of $\sim 1000$ worms on the Australian market is about AU\$50.

\section{Conclusions}

Vermicomposting is a self-promoted, self-regulated, selfimproving, self-driven, self-powered and self-enhanced, low or no energy requiring zero-waste technology, easy to construct, operate and maintain. Earthworms have real potential to both increase the rate of aerobic decomposition and composting of organic matter in the sewage sludge and also to stabilize organic residues by removing harmful pathogens and heavy metals. Of all, E. foetida is proving to be the best waste degrader and composter. It may not be able to remove toxic substances completely, but at least it changes the 'chemical make-up' of the sludge to rendering it harmless to the soil. This method has been found to comply with grade A standards for sludge stabilization (Basja et al. 2003).

The worm number and quantity (biomass) is a critical factor for vermicomposting/vermistabilization of all solid wastes besides the optimal temperature and moisture which determine worm activity. A minimum of about 100-150 adult worms per kilogram of waste would be ideal to start with for rapid

\section{References}

Appelhof, M. (1997) Worms Eat My Garbage, 2nd edn. Flower Press, Kalamazoo, Michigan, US.

ARRPET. (2005) Vermicomposting as an Eco-tool in Sustainable Solid Waste Management. The Asian Regional Research Program on Environmental Technology, Asian Institute of Technology, Anna University, India.

Bajsa O, Nair J, Mathew K \& Ho G.E (2005) Processing of sewage sludge through vermicomposting. Mathew K., Nhapi I. (eds) Water and Environment Management Series. IWA Publishing London, UK, ISBN: 1-84339-511-8.

Bajsa O., Nair J., Mathew K. \& Ho, G.E. (2004) Pathogen die off in vermicomposting process. Paper presented at the International Conference on Small Water and Wastewater Treatment Systems, Perth, 2004.

Bajsa, O., Nair, J., Mathew, K. \& Ho, G.E. (2003) Vermiculture as a tool for domestic wastewater management. Water Science and Technology, 48, 125-132.

Beyer W.N., Chaney, R.L. \& Mulhern, B. (1982) Heavy metals concentrations in earthworms from soil amended with sewage sludge. Journal of Environmental Quality, 11, 382-385.

Binet, F., Fayolle, L. \& Pussard, M. (1998) Significance of earthworms in stimulating soil microbial activity. Biology and Fertility of Soils, 27, 79-84.

Brahambhatt, A. (2006) Vermistabilization of Biosolids. 20 CP Project submitted for the partial fulfilment of the degree of Master in Environmental Engineering; School of Environmental Engineering, Griffith University, Brisbane; June 2006 (Supervisor Dr Rajiv K. Sinha).

Cardoso LR. (2002) Vermicomposting of sewage sludge: a new technology for Mexico. Journal of Water Science and Technology, 46, 153-158.

Ceccanti, B. \& Masciandaro, G. (1999) Researchers study vermicomposting of municipal and paper mill sludges. Biocycle Magazine, June.

Collier, J. (1978) Use of earthworms in sludge lagoons. In: Hartenstein R. (ed.) Utilization of Soil Organisms in Sludge Management. Virginia. USA, 133-137. biodegradation and also an odour-free process. Vermistabilization process driven by the earthworms tends to become more robust and efficient with time as the number of degrader worms grows and invades the waste biomass.

Vermiculture technology can even prevent formation of sewage sludge if the waste-eater earthworms are used in sewage treatment plants. They feed upon the waste-water solids besides significantly reducing the BOD and COD loads and the TDSS (Sinha et al. 2008a). Practicing vermicomposting technology for management of all organic wastes (solid and liquid) including sewage sludge is like 'killing two birds in one shot'. It can provide solutions to the twin objectives of safe waste management and sustainable agriculture by converting all the societal waste organics into nutritive biofertilizer which will be used by farmers to grow more food for society. Worms are assuming great significance these days in sustainable agriculture and horticulture (Sinha et al. 2009).

\section{Acknowledgements}

The authors are grateful to Prof. Roger Braddock (former Director of CESR at Griffith University) and Prof. Bofo Yu (HOS and then Director of CESR) for providing the financial support to carry out the research programme. The authors thank Jane Giffkins and Michelle in the PC2 laboratory for providing technical support for analytical studies and Ehrsam Werner for space in the PC2 laboratory for experimenting with sewage sludge.

Contreras-Ramos, S.M., Escamilla-Silva, E.M. \& Dendooven, L. (2005) Vermicomposting of biosolids with cow manure and wheat straw. Biological Fertility of Soils, 41, 190-198.

Dash, M.C. (1978) Role of earthworms in the decomposer system. In: Singh J.S. \& Gopal B. (eds) Glimpses of Ecology. India International Scientific Publication, New Delhi, 399-406.

Datar, M.T., Rao, M.N. \& Reddy, S. (1997) Vermicomposting: a technological option for solid waste management. Journal of Solid Waste Technology and Management, 24, 89-93.

Dominguez, J., Edward, C.A. \& Webster, M. (2000) Vermicomposting of sewage sludge: affect of bulking materials on growth and reproduction of the earthworm E. anderi. Journal of Pedobiologia, 44, 24-32.

Eastman, B.R. (1999) Achieving pathogen stabilization using vermicomposting. Biocycle, 62-64.

Eastman, B.R., Kane, P.N., Edwards, C.A. et al. (2001) The effectiveness of vermiculture in human pathogen reduction for USEPA biosolids stabilization. Compost Science and Utilization, 9, 38-41.

Edwards, C.A. \& Fletcher, K.E. (1988) Interaction between earthworms and microorganisms in organic matter breakdown. Agriculture Ecosystems and Environment, 24, 235-247.

Elvira, C., Sampedro, L., Benitez, E., Nogales, R. (1998) Vermicomposting of sludges from paper mills and dairy industries with Elsenia anderi. A pilot scale study. Journal of Bioresource Technology, 63, 205-211.

Fraser-Quick, G. (2002) Vermiculture - A sustainable total waste management solution. What's New in Waste Management?, 4, 13-16.

Frederickson, J., Butt, K.R., Morris, R.M. \& Daniel C. (1997) Combining vermiculture with traditional green waste composting systems. Journal of Soil Biology and Biochemistry, 29, 725-730.

Gunathilagraj, K. (1996) Earthworm: An Introduction. Indian Council of Agricultural Research Training Program; Tamil Nadu Agriculture University, Coimbatore.

Hand, P. (1988) Earthworm biotechnology. In: Greenshields, R. (ed.) Resources and Application of Biotechnology. The New Wave; MacMillan Press Ltd. US. 
Hartenstein, R. \& Bisesi, M.S. (1989) Use of earthworm biotechnology for the management of effluents from intensively housed livestock. Outlook Agriculture USA, 18, 72-76.

Hartenstein, R. \& Hartenstein, F. (1981) Physico-chemical changes affected in activated sludge by the earthworm Elsenia fetida. Journal of Environmental Quality, 10; 377-382.

Ireland, M.P. (1983) Heavy Metals Uptake in Earthworms. In: Earthworm Ecology. Chapman \& Hall, London.

Klein, J., Hughes R.J., Nair, J., Anda, M. \& G.E. Ho (2005) Increasing the quality and value of biosolids compost through vermicomposting. Paper presented at ASPIRE Asia Pacific Regional Conference on Water and Wastewater, Singapore, 10-15 July 2005.

Komarowski, S. (2001) Vermiculture for Sewage and Water Treatment Sludge. WATER, July 2001.

Loehr, R.C., Martin, J.H. \& Neuhauser, E.F. (1998) Stabilization of liquid municipal sewage sludge using earthworms. In: Edward, C.A. \& Neuhauser, E.F. (eds) Earthworms in Waste and Environmental Management. SPB Academic Publishing, The Netherlands; ISBN 90-5103-017-7.

Lotzof, M. (1999) Very large scale vermiculture on biosolids beneficiation. What's New in Waste Management?, Dec-Jan, 22-26.

Lotzof, M. (2000) Advances in Vermiculture a New Technique for Biosolids Management: A Case Study and New Research and Development Results. Paper Presented at Watertech, Sydney, Australia. Also 'Very Large Scale Vermiculture in Sludge Stabilization' (Online) <www.eidn.com.au/technicalpapervermiculture.htm > (accessed 5 August 2002).

Malley, C., Nair J. \& Ho, G. (2006) Impact of heavy metals on enzymatic activity of substrate and on composting worms Eisenia fetida. Journal of Bioresource Technology, 97, 1498-1502.

Markman, S., Guschina I.A., Barnsleya, S., Buchanan, K.L., Pascoe, D. \& Muller, C.T. (2007) Endocrine disrupting chemicals accumulate in earthworms exposed to sewage effluents. Chemosphere, 70, 119125.

Masciandaro, G., Ceccanti, B. \& Garcia, C. (2000) In-situ vermicomposting of biological sludges and impacts on soil quality. Journal of Soil Biology and Biochemistry, 32, 1015-1024.

McCarthy J. (2002) Beneficial reuse (of sewage sludge vermicompost) in action. Water, March, 72-76.

Mitchell, M.J., Horner, S.G. \& Abrams, B.L. (1980) Decompostion of sewerage sludge in drying beds and the potential role of the earthworm Elsenia fetida. Journal of Environmental Quality, 9, 373-378.

Morgan, M., Burrows, I. (1982) Earthworms/microorganisms interactions. Rothamsted Experimental Station Report.

Nair, J., Mathew, K. \& Ho, G. (2007) Earthworms and composting worms - Basics towards composting applications. Paper at Water for All Life - A Decentralised Infrastructure for a Sustainable Future. 1214 March 2007, Marriott Waterfront Hotel, Baltimore, USA.

Ndegwa, P.M. \& Thompson, S.A. (2001) Integrated composting and vermicomposting in the treatment and bioconversion of biosolids. Bioresource Technology, 76, 107-112.
Neuhauser, E.F., Loehr, R.C. \& Malecki, M.R. (1988) The potential of earthworms for managing sewage sludge. In: Edward, C.A \& Neuhauser E.F. (eds) Earthworms in Waste and Environmental Management. SPB Academic Publishing, The Hague, The Netherlands; ISBN 90-5103-017-7.

Parvaresh, A. (2004) Vermistabilization of municipal wastewater sludge with E. fetida. Iranian Journal of Environmental Health, Science and Engineering, 1, 43-50.

Singleton, D.R., Hendrix, B.F., Coleman, D.C. \& Whitemann, W.B. (2003) Identification of uncultured bacteria tightly associated with the intestine of the earthworms Lumricus rubellus. Soil Biology and Biochemistry, 35, 1547-1555.

Sinha, R.K. \& Sinha, R. (2008c) Environmental biotechnology. In: Role of Plants, Animals and Microbes in Environmental Management. Aavishkar Publishers, India, p 315. ISBN: 978-81-7910-229-9.

Sinha, R.K. (2009) Earthworms: the miracle of nature and Charles Darwin's 'Unheralded Soldiers of Mankind \& Farmer's Friends' (editorial) The Environmentalist, In press.

Sinha, R.K., Bharambe, G. \& Chowdhary, U. (2008a) Sewage treatment by vermi-filtration with synchronous treatment of sludge by earthworms: a low-cost sustainable technology over conventional systems with potential for decentralization. The Environmentalist, 28, 409-420.

Sinha, R.K., Herat, S., Agarwal, S., Asadi, R. \& Carretero, E. (2002) Vermiculture technology for environmental management: study of the action of the earthworms Eisinia foetida, Eudrilus euginae and Perionyx excavatus on biodegradation of some community wastes in India and Australia. The Environmentalist, 22, 261-268.

Sinha, R.K., Herat, S., Suhane, R.K., Singh, P.K., Chauhan, K. \& Valani, D. (2009) Embarking on a second green revolution for sustainable agriculture by earthworms and vermicompost: the miracle of plant growth promoters and protectors. The Environmentalist, In press.

Sinha, R.K., Nair, J., Bharambe, G., Patil, S. \& Bapat, P.D. (2008b) Vermiculture revolution: a low-cost and sustainable technology for management of municipal and industrial organic wastes (solid and liquid) by earthworms with significantly low greenhouse gas emissions. In: Daven, J.I. \& Klein, R.N. (eds): Progress in Waste Management Research, NOVA Science Publishers, NY, USA, pp 159-227; ISBN: 978-1-60456-235- 4.

Toms, P., Leskiw, J. \& Hettiaratchi, P. (1995) Greenhouse Gas Offsets: An Opportunity for Composting. Presentation at the 88th Annual Meeting and Exhibition, 8-12 June 1995, San Antonio, Texas, USA, pp 18-23.

USEPA. (1995) A Guide to the Biosolids Risk Assessment for the EPA. Part 503 Rule EPA/B32-B-93-005; US Environmental Protection Agency Office of Wastewater Management, Washington, D.C.

Valembois, P., Roch, P., Lassegues, M. \& Cassand, P. (1982) Anti-bacterial activity of the haemolytic system from the earthworms Elsinia fetida andrei. Invertebrate Pathology, 40, 21-27.

Vermitech. (1998) Successful biosolids beneficiation with Vermitech's large-scale commercial vermiculture facility in Redlands. Waste Disposal and Water Management in Australia, 25, 5. 